\title{
Geodetic airborne laser altimetry of Breidamerkurjökull and Skeidarárjökull, Iceland, and Jakobshavns Isbræ, West Greenland
}

\author{
JAMES B. GARVIN \\ National Aeronautics and Space Administration, Goddard Space Flight Center, Code 921, Greenbelt, MD 22071, U.S.A. \\ RichaRD S. WILLIAMS, JR \\ U.S. Geological Survey, Quissett Campus, Woods Hole, MA 02543, U.S.A.
}

\begin{abstract}
Two geodetic airborne laser altimeter (ALA) systems coupled to Global Positioning System receivers acquired submeter-resolution topographic profiles of the lower parts of Breidamerkurjökull and Skeidarárjökull, Iceland, in May 1989 and September 1991 (Skeidarárjökull) and of Jakobshavns Isbræ, Greenland, in April 1992. Maximum measured crevasse depths on Breidamerkurjökull, Skeidarárjökull and Jakobshavns Isbræ were $20.7,36.1$ and $50.2 \mathrm{~m}$, respectively. Crevasse spacings were $43 \mathrm{~m}\left(45\right.$ crevasses km$\left.{ }^{-1}\right)$ for Breidamerkur jökull, $46-51 \mathrm{~m}\left(25\right.$ crevasses $\left.\mathrm{km}^{-1}\right)$ for Skeidarárjökull and $20-40 \mathrm{~m}$ (lower part) or $50-80 \mathrm{~m}$ (upper part) of Jakobshavns Isbræ $\left(27\right.$ crevasses $\left.\mathrm{km}^{-1}\right)$. Surface slopes were $\sim 2.4^{\circ}$ for the lower $11 \mathrm{~km}$ of Breidamerkurjökull, $\sim 0.8^{\circ}$ for the lower $10 \mathrm{~km}$ of Skeidarárjökull and $1.55^{\circ}$ for the lower $28 \mathrm{~km}$ of Jakobshavns Isbræ (with a range of $0.55^{\circ}$ for the final $17 \mathrm{~km}$ to $\sim 6.3^{\circ}$ for a steep central part several $\mathrm{km}$ in length). Average longitudinal strain-rate values, estimated by assuming a bulk ice temperature of $0^{\circ} \mathrm{C}$ and a density of $880 \mathrm{~kg} \mathrm{~m}^{-3}$, ranged from $0.12 \mathrm{a}^{-1}$ for Breidamerkurjökull, to $0.63 \mathrm{a}^{-1}$ for Skeidarárjökull; values for Jakobshavns Isbræ fell between 1.3 and $1.7 \mathrm{a}^{-1}$. Remote sensing of glacier microtopography by ALA offers a potential new tool for determining crevasse morphology, spatial density and spacing, meter-scale local slopes, long-wavelength gradients and derived strain rates.
\end{abstract}

\section{INTRODUCTION}

In mathematical models of glacier dynamics, subglacial topography, ice thickness, crevasse depth and surface slope are important boundary conditions (Nye, 1957; Lliboutry, 1965; Paterson, 1981; Hutter, 1983). Typical surface-feature spacing wavelengths, including those associated with crevasses and other surface undulations, can be determined using spectral-analysis techniques, if topographic data with sufficient resolution are available. This question of resolution is a long-standing issue in quantitative geology, but it is especially relevant to glaciers because of the difficulty of measuring many of the common surface features on these landforms (e.g. crevasses) (Price, 1982; Williams and others, 1991). Remote-sensing methods for directly determining glacier-surface topography at a resolution suitable for defining or constraining fundamental glaciological variables, such as longitudinal strain rates are therefore justified (Thomas and others, 1991). Therefore, in this study, our goal is objectively and systematically to measure the depths, widths, spacings, and spatial densities of glacier-surface deformation features (e.g. crevasses), and from these measurements gain additional insights into glacier-flow dynamics and the mechanics of deformation.
On 28 May 1989, during a series of airborne laser altimeter (ALA)/Global Positioning System (GPS) surveys of various landforms in southern Iceland (Garvin and Williams, 1992a,b), ALA/GPS profiles were acquired of the lower parts of two outlet glaciers. Breidamerkurjökull and Skeidarárjökull are outlet glaciers of Vatnajökull, a large icecap $\left(8300 \mathrm{~km}^{2}\right)$ in southeastern Iceland with 43 named outlet glaciers (Williams, 1986a, 1987). Breidamerkurjökull was sel-ected for an ALA/GPS survey because it had previously been the site of an intensive aerial photogrammetric and field study of its terminus ( $10 \mathrm{~m}$ contour interval) and proglacial deposits by the Department of Geography at the University of Glasgow (Price, 1982; Welch, 1967; Howarth and Welch, 1969) and an analysis of its recession since 1894 by Sigbjarnarson (1970). Breidamerkurjökull originates in the southeastern part of Vatnajökull, and drains about $14 \%$ of the total area of the icecap (Sigbjarnarson, 1970). On 23 September 1991, after Skeidarárjökull had nearly completed a major surge, another ALA/GPS survey was carried out. On 22 April 1992, as part of a NASA laser/radar altimetry mission over the Greenland ice sheet by R.H. Thomas and colleagues, an ALA/GPS survey was completed of the lower $30 \mathrm{~km}$ of Jakobshavns Isbræ, the fastest-flowing 
glacier known (Williams, 1986b; Echelmeyer and others, 1991).

\section{METHODS}

Remote sensing of topography has most typically involved satellite radar-altimeter sensors such as Seasat, GEOS-3, Geosat and most recently ERS-1; see Bufton (1989) for general details. Such orbital altimeter systems provide kilometer-scale horizontal sampling of sea-surface and ice-sheet topography, with a statistical vertical precision of greater than $1 \mathrm{~m}$. However, such radar systems are unable to measure the spatially varying topography of glaciers at length scales of meters to tens of meters. Stereophotogrammetric analysis of low-altitude aerial phtographs was, until recently, the only means for determining sub- $10 \mathrm{~m}$ scale topographic characteristics of rugged, complex surfaces, such as those commonly encountered on highly crevassed regions of glaciers or steeply sloping glaciers. New airborne and spaceborne synthetic aperture radar interferometric techniques offer great promise for mapping in two dimensions the 10 $100 \mathrm{~m}$ scale topographic properties of glacier surfaces at vertical resolutions approaching $1 \mathrm{~m}$ (Zebker and Goldstein, 1986; Gabriel and others, 1989).

Bufton (1989), Bufton and others (1991) and Gardner (1992) describe the current state-of-the-art in airborne and spaceborne laser-altimeter instruments, with attention to those sensors developed by the National Aeronautics and Space Administration (NASA). We exploited recent technological innovations in a NASA laser-altimeter system known as the Airborne Oceanographic Lidar (AOL) (Hoge and others, 1984) and the Airborne Terrain Laser Altimeter System (ATLAS), both operating in the terrain profiling mode, to acquire geodetically precise topographic profiles of the two outlet glaciers in southeastern Iceland and one in West Greenland. The incorporation of Global Positioning System (GPS) aircraft-navigation instrumentation into the AOL system (Krabill and Martin, 1987) permitted us to quantify aircraft vertical position to approximately $30-$ $50 \mathrm{~cm}$ over length scales of tens to hundreds of $\mathrm{km}$. The combination of a high-sample-rate aircraft laser altimeter system, such as the AOL with kinematic GPS tracking of aircraft position enabled us, for the first time, from an aircraft, to measure surface topography of a glacier with a vertical precision of approximately $30 \mathrm{~cm}$ root-meansquare (r.m.s.). Our GPS-tracked AOL system topographic profile down Breidamerkurjökull in May 1989 was the initial demonstration of a remote-sensing method we propose to call "geodetic airborne laser altimetry" or GALA. A high signal-to-noise GALA topographic profile extending from a position on Breidamerkurjökull at $64.2^{\circ} \mathrm{N}, 16.3^{\circ} \mathrm{W}$, down-glacier to the terminus at $64.0^{\circ} \mathrm{N}, 16.2^{\circ} \mathrm{W}$ was acquired with horizontal sampling of $\sim 0.5 \mathrm{~m}$ and with vertical control of approximately $30 \mathrm{~cm}$ r.m.s. The total profile length of $16.6 \mathrm{~km}$ from Breidamerkurjökull to the ocean required $\sim 3 \mathrm{~min}$ to acquire and generated about 36000 independent elevation samples across the glacier surface. The data were acquired at an approximately constant altitude of $\sim 400 \mathrm{~m}$ above the surface of the glacier. Further details
AOLGPS: BREIDAMERKURJÖKULL CREVASSES

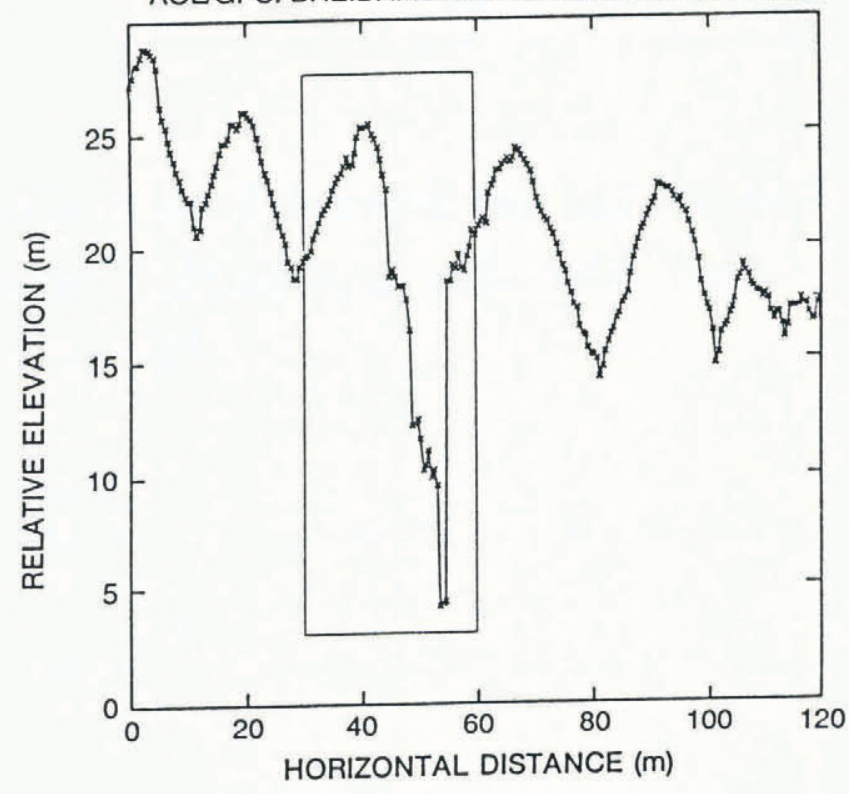

Fig. 1. Airborne laser altimeter ( $A O L)$ profile of a deep crevasse $(20.7 \mathrm{~m})$ near the terminus of Breidamerkurjökull, Iceland, on 28 May 1989.

of the design and application of GALA instrumentation can be found in Krabill and Martin (1987), Bufton and others (1991), Hoge and others (1984). The rest of this paper demonstrates how GALA topographic data can be used to quantify morphologic characteristics of any glacier surface, with examples from two glaciers in Iceland and one in Greenland.

\section{GALA DATA}

A NASA P-3 research aircraft equipped with a GALA system (for example, AOL with Motorola "Eagle" GPS receivers) was deployed to: (1) southeastern Iceland on 28 May 1989 to acquire topographic profiles of the lower part of Breidamerkurjökull (Fig. 1) and Skeidarárjökull; (2) southeastern Iceland on 23 September 1991 to acquire topographic profiles of the lower part of the post-surge Skeidarárjökull (Figs 2a, b and 3); and (3) Greenland on 22 April 1992 to acquire topographic profiles of the lower part of the fast-flowing Jakobshavns Isbræ (Figs 4 and 5a, $\mathrm{b}, \mathrm{c})$. The capability of directly measuring the extreme topography of crevasses (Figs 1 and 5c) by means of GALA techniques enables quantitative comparisons of derived physical parameters such as strain rate $\left(\dot{\epsilon}_{\mathrm{x}}\right)$ across the entire length of a complex glacier. The application of standard signal analysis methods (Turcotte, 1992) for rapid determination of wavelengths (for example, typical spacing) of surface features such as crevasses is possible with GALA datasets.

\section{CREVASSE DEPTH}

Quantification of the microtopography and horizontal spacing of major transverse crevasses provides significant 

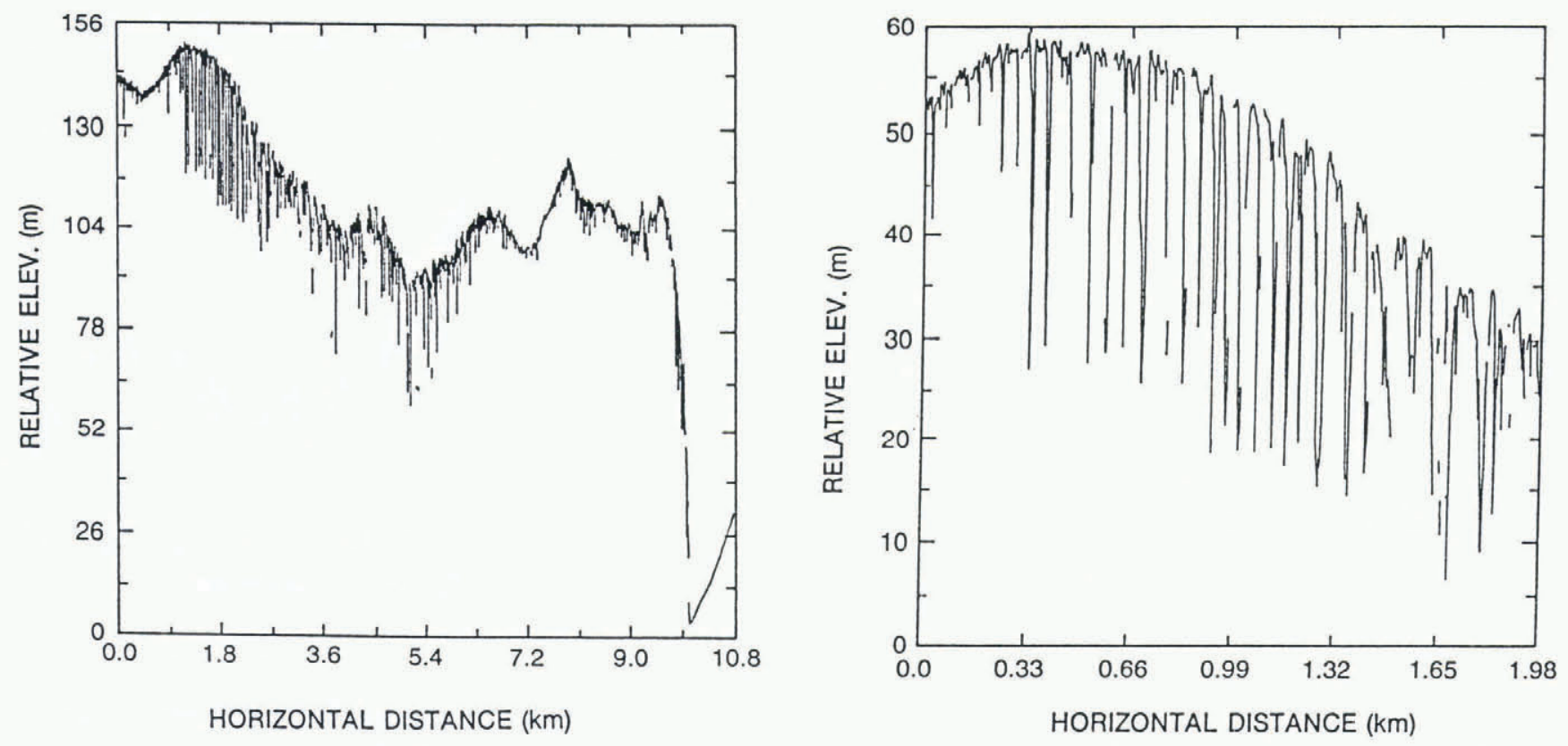

Fig. 2. Airborne laser altimeter (ATLAS) profiles of crevasses on Skeidarárjökull, Iceland, on 23 September 1991, following a surge: a, about $10 \mathrm{~km}$ up-glacier from the terminus (right side of profile) and b, a region $8 \mathrm{~km}$ up-glacier from the terminus (see Figure 3 for oblique aerial photograph).

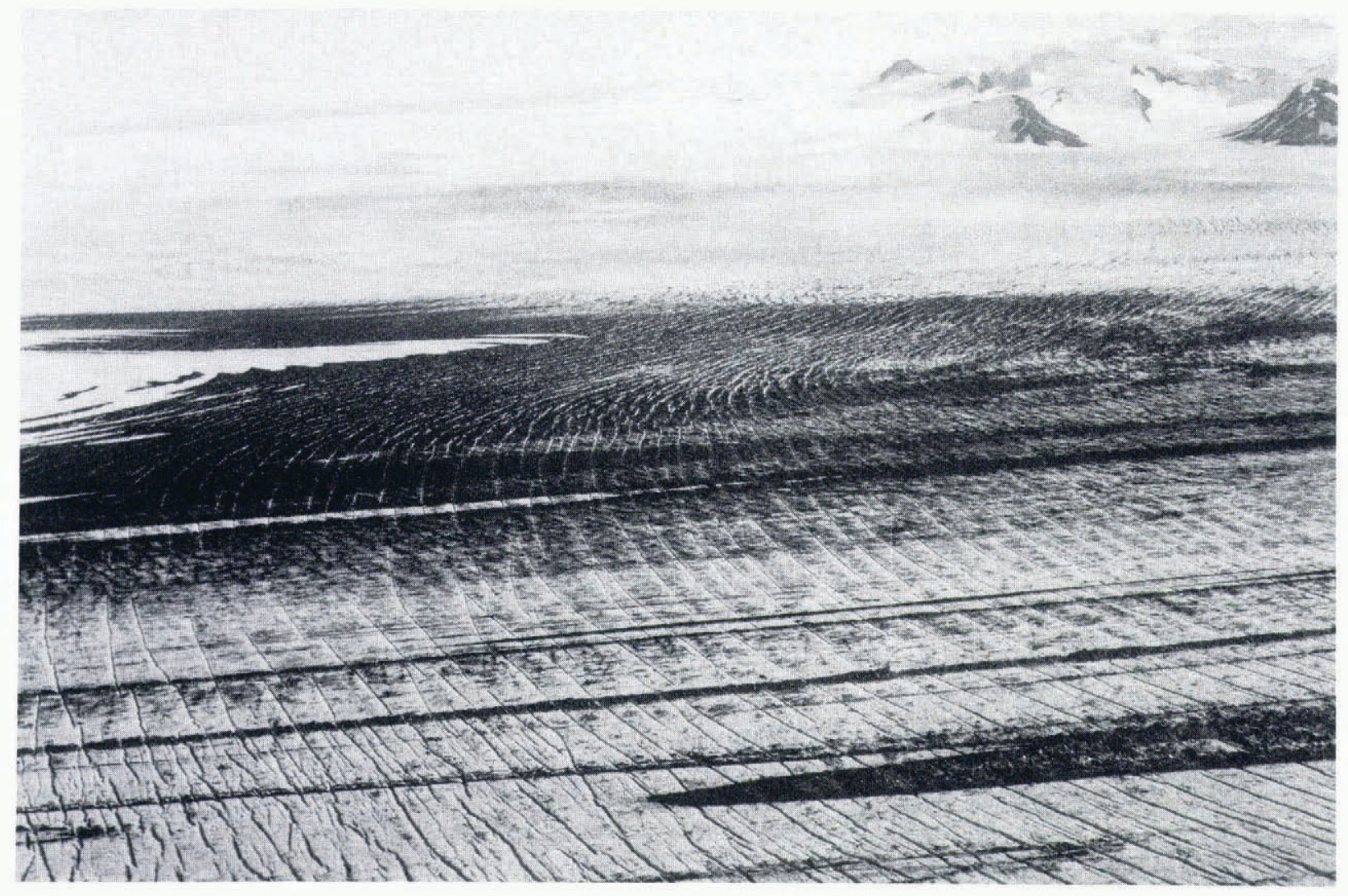

Fig. 3. Oblique $35 \mathrm{~mm}$ aerial photograph looking east at a highly crevassed region of Skeidarárjökull, Iceland, following a surge. Photograph acquired by 7 . B. Garvin simultaneously with the ALA profile shown in Fig. $2 b$. 


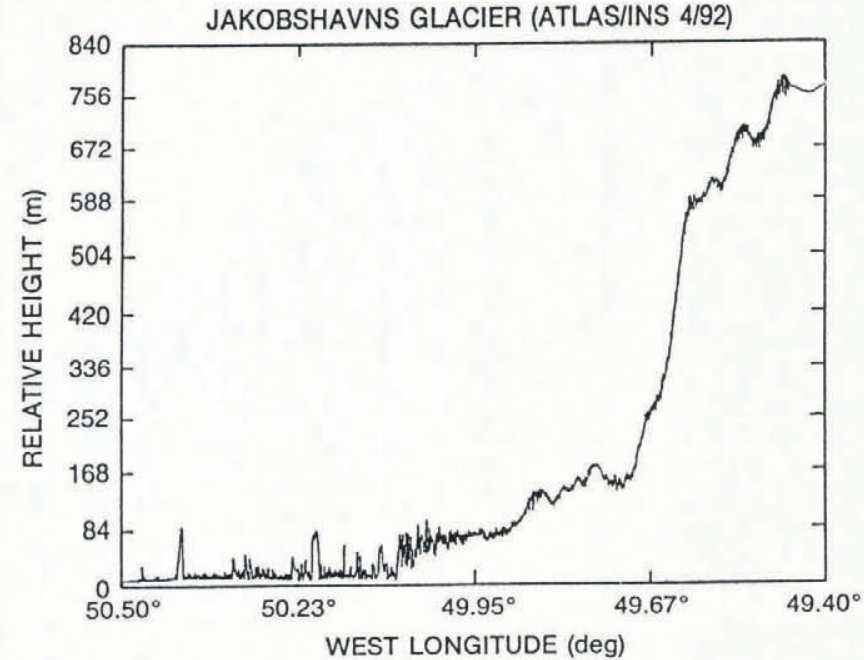

Fig. 4. Airborne laser altimeter (ATLAS) profile of the lower $17 \mathrm{~km}$ of Jakobshavns Isbra, Greenland, on 22 April 1992. Iceberg-filled fiord to the left of the terminus. Note the concentration of crevasses and surface undulations upglacier from the terminus.

new information about glacier surfaces. The ALA successfully measured crevasse depths on the lower part of the three glaciers. Only Breidamerkurjökull seems to have been affected by significant snow accumulation in its crevasses; typical crevasse depths ranged from 8.6 to $13.5 \mathrm{~m}$. The maximum crevasse depth was $20.7 \mathrm{~m}$ near the terminus (Fig. 1). Skeidarárjökull had crevasse depths of from 18 to $22 \mathrm{~m}$; the maximum depth measured was $36.1 \mathrm{~m}$. Jakobshavns Isbræ had typical crevasses in a depth range of 21 to $25 \mathrm{~m}$; the maximum crevasse depth was $50.2 \mathrm{~m}$ (Fig. 5c). At wavelengths between 10 and $100 \mathrm{~m}$, highly crevassed glacier surfaces display large topographic variances (up to $22 \mathrm{~m}$ on Breidamerkurjökull) with local slopes in excess of $41^{\circ}$. This observation suggests that advanced synthetic aperture radar systems, including those employing interferometric techniques to measure topography at spatial scales from $10-100 \mathrm{~m}$, will have difficulties separating the effects of $10-30 \mathrm{~cm}$ roughness from $10-100 \mathrm{~m}$ scale topographic variance associated with deep crevasses (Gabriel and others, 1989).

\section{CREVASSE SPACING}

Spectral analysis of periodic topography has been employed for more than 30 years as a standard technique for terrain characterization (Turcotte, 1992; Garvin and Williams, 1992a). We employed such techniques to estimate the power-spectral density (PSD) function of a surface in the form of an equation that relates the amplitude (or power) of the topography $A$ to a given wavelength $(\lambda)$ :

$$
A=k \lambda^{\beta},
$$

where $k$ and $\beta$ are constants derived from a least-squares regression of the data relating $A$ to $\lambda$ for a topographic profile. We can then investigate whether there are

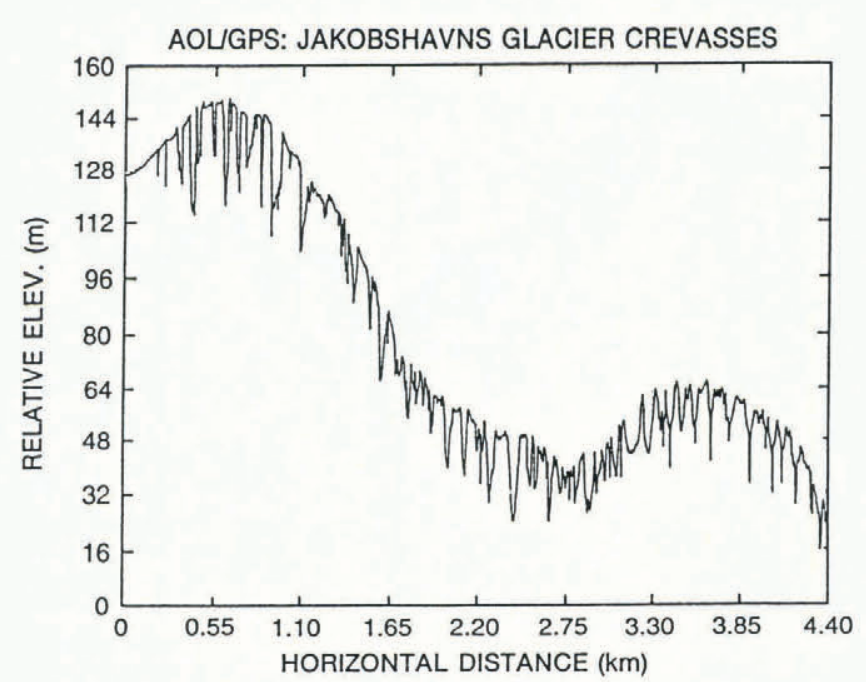

a

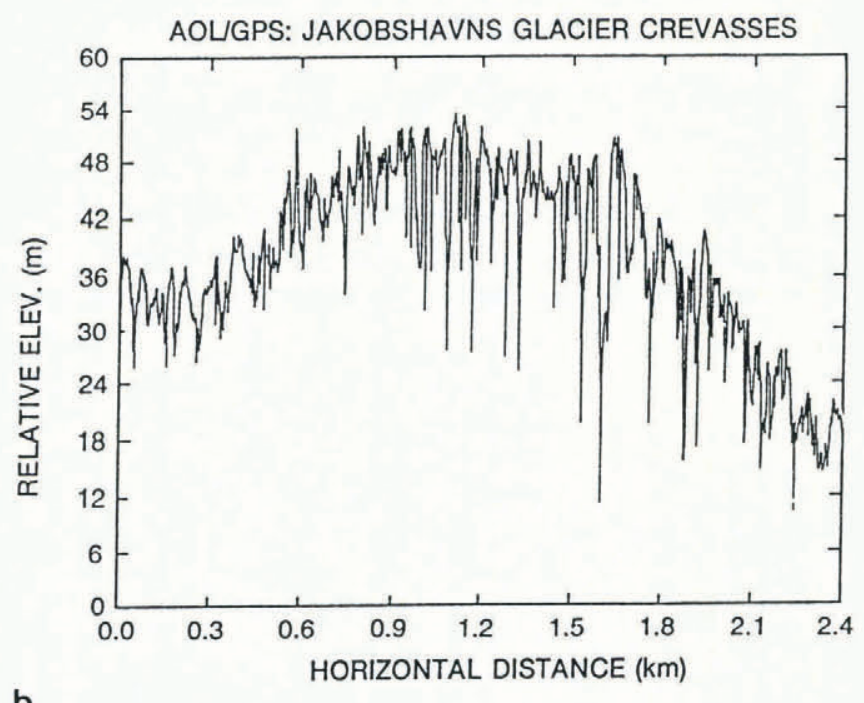

b

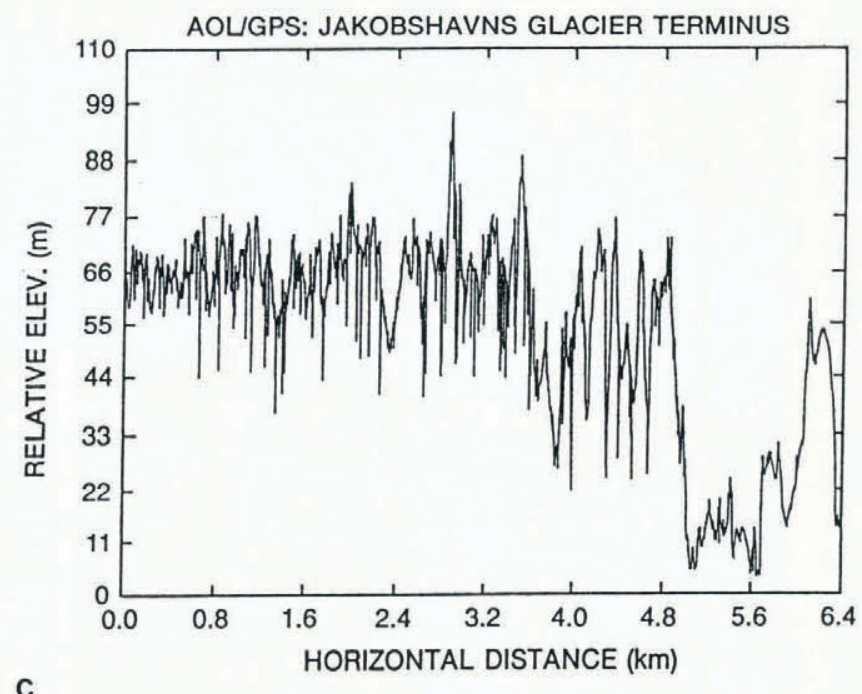

Fig. 5. Enlarged part of airborne laser altimeter ( $A O L)$ profile shown in Figure 4: a, crevasses on surface undulations in the upper part of the profile; $b$, crevasses on a surface undulation in the middle part of the profile; and $c$, the $70 \mathrm{~m}$ high terminus and lower part of the profile. 
significant "dominant wavelengths" associated with a given surface sub-unit by subtracting the best-fitting power law from the original PSD function. From this process, we can identify statistically significant residual wavelengths and attempt to relate them to periodic crevasse spacing. A PSD analysis of the lower, snow-free part of Breidamerkurjökull gave a typical crevasse spacing of $43 \mathrm{~m}$; Skeidarárjökull had crevasses typically spaced from 46 to $51 \mathrm{~m}$. Jakobshavns Isbræ had a typical crevasse spacing of $20-41 \mathrm{~m}$ in its lower part and $50-80 \mathrm{~m}$ in its upper part.

\section{CREVASSE DENSITY}

The spatial density of crevasses on the three glaciers was estimated from the GALA data. For the lower few kilometers of Breidamerkurjökull, the spatial density of crevasses along the center line of the glacier was $\sim 45$ crevasses $\mathrm{km}^{-1}$ (Table 1), in contrast with 25 crevasses $\mathrm{km}^{-1}$ for the final $10 \mathrm{~km}$ (e.g. $10 \mathrm{~km}$ up-glacier from the terminus) of Skeidarárjökull. The crevasse density statistics for typical crevassed sections of Jakobshavns Isbræ varied from $\sim 19$ crevasses $\mathrm{km}^{-1}$ (as measured from the $3.27 \mathrm{~m}$ sampling resolution of the ATLAS dataset) to $\sim 27$ crevasses $\mathrm{km}^{-1}$ (as estimated from the $0.54 \mathrm{~m}$ sampling resolution of the AOL data). This demonstrates that a six-fold increase in horizontal sampling frequency (for example, from 3.27 to $0.54 \mathrm{~m}$ ) increases the detectability of apparent crevasses by up to $46 \%$.

\section{SURFACE SLOPE}

Surface slopes for Breidamerkurjökull were $\sim 2.44^{\circ}$ for the lower $13 \mathrm{~km}$ and $\sim 0.8^{\circ}$ for the lower $10 \mathrm{~km}$ of Skeidarárjökull. Local slopes, depending on the baseline selected, can be quite variable. Jakobshavns Isbræ has a $1.55^{\circ}$ slope over its lower $28 \mathrm{~km}$; a slope of $\sim 6.3^{\circ}$ over its central part, and a slope of $0.55^{\circ}$ (Fig. 4) over the final $17 \mathrm{~km}$, including the floating terminus.

\section{DERIVED STRAIN RATE}

In his summary on the physics of glaciers, Paterson (1981) presented a simple theory to account for the maximum depth of crevasses originally formulated by Nye (1957). Nye (1957) first developed a simple relationship between maximum crevasse depth $d$ and longitudinal strain rate $\dot{\epsilon}_{\mathbf{x}}$ as follows:

$$
d=2\left(\dot{\epsilon}_{\mathbf{x}} / A\right)^{1 / \mathrm{n}}(\rho g)^{-1}
$$

where $\rho$ is the density of ice, $g$ is the gravitational acceleration, and $A$ and $n$ are glacier-ice flow-law parameters. Nye's model predicts the strain rate $\dot{\epsilon}_{\mathbf{x}}$ (in $\mathrm{a}^{-1}$ ) that corresponds to the depth within a glacier at which the principal tensile stress approaches zero. We can solve the Nye equation for $\dot{\epsilon}_{\mathbf{x}}$, because our GALA measurements provide estimates of $d$ for a large number of crevasses within the glacier. Solving for $\dot{\epsilon}_{\mathrm{x}}$ in terms of $d$ yields:

$$
\dot{\epsilon}_{\mathrm{x}}=A(0.5 \rho g d)^{n} \text {. }
$$

If we assume an $n=3$ flow law and using an estimated average temperature for temperate glacier ice in southeastern Iceland of $\sim 0^{\circ} \mathrm{C}$, we can use Paterson (1981) to select a suitable value for $A: A=5.3 \times 10^{-15} \mathrm{~s}^{-1}(\mathrm{kPa})^{-3}$ at $0^{\circ} \mathrm{C}$. If we let $\rho=880 \mathrm{~kg} \mathrm{~m}^{-3}$ for ice and $g=$ $9.81 \mathrm{~m} \mathrm{~s}^{-2}$, we can then estimate $\dot{\epsilon}_{\mathrm{x}}$ for any measured value of $d$ as follows:

$$
\dot{\epsilon}_{\mathrm{x}}=1.34 \times 10^{-5} d^{3}\left(\text { in }^{-1}\right)
$$

where $d$ is the maximum crevasse depth in meters. Most of the largest crevasses measured on Breidamerkurjökull were about $20 \mathrm{~m}$ deep, suggesting strain rates in the vicinity of $0.110 \mathrm{a}^{-1}$, that is within the range observed

\begin{tabular}{|c|c|c|c|c|c|c|c|c|}
\hline Glacier name & $\begin{array}{l}\text { Data } \\
\text { source }\end{array}$ & $\begin{array}{c}\text { Down-glacier } \\
\text { slope }\end{array}$ & $\begin{array}{c}\text { Crevasse } \\
\text { spatial } \\
\text { density }\end{array}$ & $\begin{array}{c}\text { Maximum } \\
\text { crevasse } \\
\text { depth }\end{array}$ & $\begin{array}{c}\text { Typical } \\
\text { crevasse } \\
\text { spacing }\end{array}$ & $\begin{array}{l}\text { Nye } \\
\text { strain } \\
\text { rate }\end{array}$ & $\begin{array}{c}\text { Dilatation } \\
\text { stagnant } \\
\text { ice }\end{array}$ & $\begin{array}{l}\text { Dilatation } \\
\text { active ice }\end{array}$ \\
\hline & sampling & $\circ$ & crevasses $\mathrm{km}^{-1}$ & $\mathrm{~m}$ & $\mathrm{~m}$ & $1 \mathrm{a}^{-1}$ & $1 \mathrm{a}^{-1}$ & $1 \mathrm{a}^{-1}$ \\
\hline $\begin{array}{l}\text { Breidamerkurjökull } \\
(5 / 89)\end{array}$ & $\begin{array}{c}\text { AOL/GPS } \\
(\mathrm{d} x=0.5 \mathrm{~m})\end{array}$ & 2.4 & 45 & 20.7 & 43 & 0.119 & 0.017 & 0.060 \\
\hline $\begin{array}{l}\text { Skeidarárjökull } \\
(9 / 91)\end{array}$ & $\begin{array}{c}\text { ATLAS } \\
(\mathrm{d} x=1.7 \mathrm{~m})\end{array}$ & 0.8 & 25 & 36.1 & 51 & 0.630 & 0.092 & 0.316 \\
\hline $\begin{array}{l}\text { Jakobshavns Isbræ } \\
(4 / 92)\end{array}$ & $\begin{array}{l}\text { ATLAS/INS } \\
(\mathrm{d} x=3.2 \mathrm{~m})\end{array}$ & $1.6^{* *}$ & 19 & 45.6 & 41 & 1.27 & 0.185 & 0.637 \\
\hline $\begin{array}{l}\text { Jakobshavns Isbræ } \\
(4 / 92)\end{array}$ & $\begin{array}{l}\text { ATLAS/GPS } \\
(\mathrm{d} x=0.5 \mathrm{~m})\end{array}$ & $1.6^{* *}$ & 27 & 50.2 & 28 & 1.70 & 0.247 & 0.850 \\
\hline
\end{tabular}
(e.g. $\dot{\epsilon}_{\mathrm{x}}$ are $0.004-0.16 \mathrm{a}^{-1}$ ) by Hambrey and Müller

Table 1. Laser altimetry of glacier crevasses

* Nye theory strain rate $\dot{\epsilon}_{\mathrm{x}} @ \mathrm{~T}=0^{\circ} \mathrm{C}, \rho$ (ice) $=880 \mathrm{~kg} \mathrm{~m}^{3}$ for $n=3$ (temperate case).

** Varies from 0.5 to $6.3^{\circ}$. 
(1978) for White Glacier on Axel Heiberg Island, northern Canada, and also from Lliboutry (1965) for Mer de Glace in France $\left(\dot{\epsilon}_{\mathbf{x}}=0.14 \mathrm{a}^{-1}\right)$. We explored the sensitivity of our results to variations in glacier ice density and temperature. Temperature affects computed $\dot{\epsilon}_{\mathrm{x}}$ values most severely; a decrease of $10^{\circ} \mathrm{C}$ alters $\dot{\epsilon}_{\mathrm{x}}$ by a factor of 10 (downward), while variations in bulk ice density affect $\dot{\epsilon}_{\mathrm{x}}$ values by a factor of $1-4$ at most (e.g. varying from $830-900 \mathrm{~kg} \mathrm{~m}^{-3}$ increases the strain rates by a factor of 4). Longitudinal strain-rate estimates are based upon the observed maximum depths of the largest crevasses within the GALA profile acquired and may not necessarily be representative.

Given the typical morphometry of glacier crevasses and the fact that most contain snow at the bottom unless newly formed during the ablation season, it is probable that our GALA data systematically underestimated the maximum depths of the crevasses (Fig. 1). We believe, however, that routine GALA surveys of glaciers could provide an extensive database of crevasse depths from which to explore further strain rates within various types of glaciers.

Given the assumptions implicit in the Nye (1957) model that relates maximum crevasse depth to longitudinal strain rate $\dot{\epsilon}_{\mathbf{x}}$, one can evaluate the dilatations (in $\mathrm{a}^{-1}$ ) that can be estimated from crevasse depths using relationships developed by Lliboutry (1965). Lliboutry (1965) suggested that for active temperate glaciers, the dilatation $|a|$ can be estimated using an equation of the form:

$$
|a|=6.72 \times 10^{-6} d_{\text {crev }}^{3}
$$

given crevasse depth $d_{\text {crev }}$ in meters. This equation is very similar to the Nye (1957) strain rate model for $n=3$, when the temperature is approximately $-5^{\circ} \mathrm{C}$. When the glacier is in a stagnant state, such as is the case in its lower part after a surge (for example, Skeidarárjökull in the late summer of 1991), Lliboutry (1965) suggests that the dilatation $|a|$ in $\mathrm{a}^{-1}$ is:

$$
|a|=1.95 \times 10^{-6} d_{\text {crev }}^{3} .
$$

Table 1 summarizes the ranges of dilatations computed using the Lliboutry equations above as a function of the observed maximum crevasse depths, in comparison with the Nye model strain rates (for $n=3, T=0^{\circ} \mathrm{C}, \rho=$ $\left.880 \mathrm{~kg} \mathrm{~m}^{-3}\right)$. The maximum dilatations are generally a factor of two lower than the Nye model strain rates, as would be expected (Lliboutry, 1965). Thus, our impression is that there is reasonable evidence that the strain rates for highly active or recently surged outlet glaciers in Iceland and Greenland range from 0.32 to $1.7 \mathrm{a}^{-1}$, in contrast with less active glaciers such as Breidamerkurjökull.

\section{SUMMARY}

Sub-meter resolution geodetic airborne laser altimeter (GALA) profiles of Breidamerkurjökull and Skeidarárjökull outlet glaciers in Iceland and of Jakobshavns Isbræ in Greenland were analyzed. The maximum crevasse depth ranges from $21 \mathrm{~m}$ on Breidamerkurjökull (Fig. 1) to $50.2 \mathrm{~m}$ on Jakobshavns Isbræ (Fig. 5c), assuming no snow in the crevasses. Typical crevasse spacings and density for Breidamerkurjökull were $43 \mathrm{~m}$ from power-spectral density analysis ( 45 crevasses $\mathrm{km}^{-1}$ ), $46-51 \mathrm{~m}$ on Skeidarárjökull ( 25 crevasses $\mathrm{km}^{-1}$ ), and $20-41 \mathrm{~m}$ for the lower part of Jakobshavns Isbræ and $50-80 \mathrm{~m}$ for its upper part (18 to $20 \mathrm{~km}^{-1}$ ). Surface slopes were $\sim 2^{\circ}$ for the lower $11 \mathrm{~km}$ of Breidamerkurjökull and $\sim 0.8^{\circ}$ for the lower $10 \mathrm{~km}$ of Skeidarárjökull. Jakobshavns Isbræ has a $1.55^{\circ}$ slope over its lower $28 \mathrm{~km}$ but the final $17 \mathrm{~km}$ has a slope of $0.55^{\circ}$. The steeper central part has a surface slope of $\sim 6.3^{\circ}$ (Fig. 4 ).

Nye model strain rates range from $0.12 \mathrm{a}^{-1}$ for the Breidamerkurjökull outlet glacier to as high as $0.63 \mathrm{a}^{-1}$ for the recently surged Skeidarárjökull outlet glacier. In contrast are the strain rates inferred for the heavily crevassed regions of Jakobshavns Isbræ in West Greenland, where values in excess on $1.2 \mathrm{a}^{-1}$ were computed. Dilatations computed using the Lliboutry (1965) model for active glacier ice are generally a factor of two lower than the Nye strain rates, and range from $0.06 \mathrm{a}^{-1}$ for Breidamerkurjökull to $0.85 \mathrm{a}^{-1}$ for Jakobshavns Isbræ. Both the strain-rate and dilatation values derived from our GALA measurements of maximum crevasse depths for the three outlet glaciers suggest deformation rates that exceed those previously summarized in the literature (e.g. Lliboutry, 1965; Paterson, 1981). Glacier-flow rates can also be inferred from our results; e.g. $3910 \mathrm{~m} \mathrm{a}^{-1}$ for Jakobshavns Isbræ and $900 \mathrm{ma}^{-1}$ for Skeidarárjökull. Sub-meter-scale topographic cross-section are required to characterize accurately difficult-to-measure surface features of glaciers, such as crevasses. Future Earth-orbiting altimeter systems, including those under study as part of NASA's Earth Observing System (EOS) Project, will not be able to provide the spatial resolution necessary (e.g. $\leq 10 \mathrm{~m}$ ) to characterize salient surface textures on glaciers for the purpose of characterizing aspects of glacier surface deformation and flow. GALA methods may be the only practical and reliable means for measuring accurately the depth and morphometry of glacier crevasses.

\section{ACKNOWLEDGEMENTS}

We are grateful for the engineering and science support in GPS data acquisition and reduction provided by $\mathrm{W}$. Krabill and E. B. Frederick; operation of the AOL laser altimeter by R.N. Swift, J. Yungel and W. Wright; Mission Manager D. Pierce and the P-3A (NASA-428) pilots, G. Postell and V. Rabine, provided excellent support. Data reduction and analysis by M. Taylor and J. B. Blair is much appreciated. The project was indirectly supported by NASA RTOP 465-44-03 (Iceland Volcanology and Geomorphology) through M. Baltuck and R. Brakenridge of NASA Headquarters. We thank also the National Research Council and the Iceland Council of Science of Iceland for approving research permits, and C. J. Slater for moral support and table preparation.

\section{REFERENCES}

Bufton, J. L. 1989. Laser altimetry measurements from aircraft and spacecraft. Proc. IEEE, 77, 463-477. 
Bufton, J. L., J. B. Garvin, L. F. Cavanaugh, L. RamosIzquerdo, T. Clem and W. Krabill. 1991. Airborne lidar for profiling of surface topography. Opt. Eng., 30, 71-78.

Echelmeyer, K., T. S. Clarke and W. D. Harrison. 1991. Surficial glaciology of Jakobshavns Isbræ, West Greenland: Part I. Surficial morphology. J. Glaciol., 37(127), 368-382.

Gabriel, A. K., R. M. Goldstein and H. A. Zebker. 1989. Mapping small elevation changes over large areas: differential radar interferometry. 7. Geophys. Res., 94(B7), 9183-9191.

Gardner, C.S. 1992. Ranging performance of satellite laser altimeters. Urbana-Champaign, IL, University of Illinois.( Report EOSL 92-002.)

Garvin, J. B. and R.S. Williams, Jr. 1992a. Icelandic lava-shield volcanoes: scaling of topography, slopes, and morphometry. EOS, 73(14), 58-59.

Garvin, J. B. and R.S. Williams, Jr. 1992b. Remote sensing studies of the geomorphology of Surtsey, 19871991. Reykjavik Surtsey Res. Prog. Rep, X, 57-71.

Hambrey, M.J. and F. Müller. 1978. Structures and ice deformation in the White Glacier, Axel Heiberg Island, Northwest Territories, Canada. 7. Glaciol., 20(82), 41-66.

Hoge, F.E., W. B. Krabill and R. N. Swift. 1984. The reflection of airborne UV laser pulses from the ocean. Marine Geodesy, 8, 313-344.

Howarth, P.J. and R. Welch. 1969. Breidamerkurjökull, southeast Iceland. Two map sheets (August 1945 and August 1965). Scale 1:30,000. Glasgow, University of Glasgow. Department of Geography.

Hutter, K. 1983. Theoretical glaciology; material science of ice and the mechanics of glaciers and ice sheets. Dordrecht, etc., D. Reidel Publishing Co./Tokyo, Terra Scientific Publishing Co.

Krabill, W. B. and C. F. Martin. 1987. Aircraft positioning using Global Positioning System carrier phase data. Navigation J., 34, 1-21.

Lliboutry, L. 1965. Traité de glaciologie. Tome 2. Paris, Masson et Cie.
Nye, J.F. 1957. The distribution of stress and velocity in glaciers and ice-sheets. Proc. R. Soc. London, Ser. A, 239(1216), 113-133.

Paterson, W.S.B. 1981. The physics of glaciers. Second edition. Oxford, etc., Pergamon Press.

Price, R.J. 1982. Changes in the proglacial area of Breidamerkurjökull, southeastern Iceland: 1890-1980. Jökull, 32, 29-35.

Sigbjarnarson, G. 1970. On the recession of Vatnajökull. Jökull, 20, 50-61.

Thomas, R.H., K. Jezek, W. Krabill and K. Kuivinen. 1991. Ice-sheet elevation profiles from airborne laser altimetry. EOS, 72(44), 149.

Turcotte, D. L. 1992. Fractals and chaos in geology and geophysics. New York, etc., Cambridge University Press.

Welch, R. 1967. The application of aerial photography to the study of a glacier area, Breidamerkurjökull, Iceland. (Ph.D. thesis, University of Glasgow.)

Williams, R.S., Jr. 1986a. Breidamerkurjökull, southeastern Iceland. In Short, N. M. and R. W. Blair, Jr, eds. Geomorphology from space. A global overview of regional landforms. Washington, DC, National Aeronautics and Space Administration, 568-569. (SP-486.)

Williams, R.S., Jr. 1986b. Jakobshavns Isbræ, Greenland. In Short, N.M. and R. W. Blair, Jr, eds. Geomorphology from space. A global overview of regional landforms. Washington, DC, National Aeronautics and Space Administration, 542-543. (SP-486.)

Williams, R.S., Jr. 1987. Satellite remote sensing of Vatnajökull, Iceland. Ann. Glaciol., 9, 127-135.

Williams, R.S., Jr, D. K. Hall and C. S. Benson. 1991. Analysis of glacier facies using satellite techniques. $\mathcal{J}$. Glaciol., 37(125), 120-128.

Zebker, H.A. and R. M. Goldstein. 1986. Topographic mapping from interferometric synthetic aperture radar observations. F. Geophys. Res., 91(B5), 4993-4999.

The accuracy of references in the text and in this list is the responsibility of the authors, to whom queries should be addressed. 